\title{
Front Matter: Volume 10730
}

, "Front Matter: Volume 10730," Proc. SPIE 10730, Nanoengineering:

Fabrication, Properties, Optics, and Devices XV, 1073001 (8 October 2018); doi: $10.1117 / 12.2515524$

SPIE Event: SPIE Nanoscience + Engineering, 2018, San Diego, California, United SPIE. States 


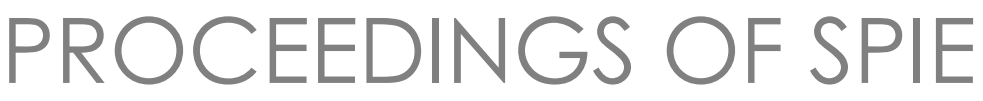

\title{
Nanoengineering: Fabrication, Properties, Optics, and Devices XV
}

\author{
Balaji Panchapakesan \\ Anne E. Sakdinawat \\ André-Jean Attias \\ Elizabeth A. Dobisz \\ Editors
}

21-23 August 2018

San Diego, California, United States

Sponsored and Published by

SPIE 
The papers in this volume were part of the technical conference cited on the cover and title page. Papers were selected and subject to review by the editors and conference program committee. Some conference presentations may not be available for publication. Additional papers and presentation recordings may be available online in the SPIE Digital Library at SPIEDigitallibrary.org.

The papers reflect the work and thoughts of the authors and are published herein as submitted. The publisher is not responsible for the validity of the information or for any outcomes resulting from reliance thereon.

Please use the following format to cite material from these proceedings:

Author(s), "Title of Paper," in Nanoengineering: Fabrication, Properties, Optics, and Devices XV, edited by Balaji Panchapakesan, Anne E. Sakdinawat, André-Jean Attias, Elizabeth A. Dobisz, Proceedings of SPIE Vol. 10730 (SPIE, Bellingham, WA, 2018) Seven-digit Article CID Number.

ISSN: 0277-786X

ISSN: 1996-756X (electronic)

ISBN: 9781510620315

ISBN: 9781510620322 (electronic)

Published by

SPIE

P.O. Box 10, Bellingham, Washington 98227-0010 USA

Telephone +1 3606763290 (Pacific Time) · Fax +1 3606471445

SPIE.org

Copyright (C) 2018, Society of Photo-Optical Instrumentation Engineers.

Copying of material in this book for internal or personal use, or for the internal or personal use of specific clients, beyond the fair use provisions granted by the U.S. Copyright Law is authorized by SPIE subject to payment of copying fees. The Transactional Reporting Service base fee for this volume is $\$ 18.00$ per article (or portion thereof), which should be paid directly to the Copyright Clearance Center (CCC), 222 Rosewood Drive, Danvers, MA 01923. Payment may also be made electronically through CCC Online at copyright.com. Other copying for republication, resale, advertising or promotion, or any form of systematic or multiple reproduction of any material in this book is prohibited except with permission in writing from the publisher. The CCC fee code is 0277$786 \mathrm{X} / 18 / \$ 18.00$.

Printed in the United States of America.

Publication of record for individual papers is online in the SPIE Digital Library.

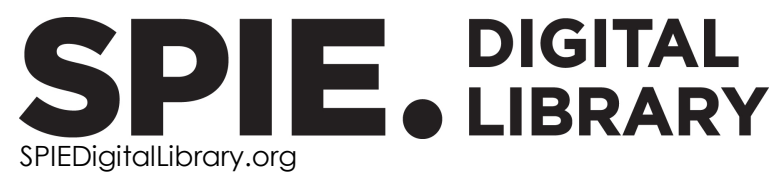

Paper Numbering: Proceedings of SPIE follow an e-First publication model. A unique citation identifier (CID) number is assigned to each article at the time of publication. Utilization of CIDs allows articles to be fully citable as soon as they are published online, and connects the same identifier to all online and print versions of the publication. SPIE uses a seven-digit CID article numbering system structured as follows:

- The first five digits correspond to the SPIE volume number.

- The last two digits indicate publication order within the volume using a Base 36 numbering system employing both numerals and letters. These two-number sets start with $00,01,02,03,04$, 05, 06, 07, 08, 09, 0A, OB ... 0Z, followed by 10-1Z, 20-2Z, etc. The CID Number appears on each page of the manuscript. 


\title{
Contents
}

\author{
$\checkmark \quad$ Authors \\ vii Conference Committee
}

NANO AND MICRO OPTICS

1073007 Cylindrical vector beam sorting based on anisotropic geometric optical transformation [10730-5]

ENERGY HARVESTING AND STORAGE TECHNOLOGY

$10730 \mathrm{OA}$ Improving dielectric nano-resonator-based antireflection coatings for photovoltaics [10730-9]

$10730 \mathrm{OB} \quad \mathrm{MnFe}_{2} \mathrm{O}_{4}$ and $\mathrm{MnO}_{2}$ nanoparticle-based high-temperature, air-stable, long-term antioxidation cermet solar selective absorbers [10730-10]

10730 OC Preparation, characterization, and supercapasitive properties of CoO-NiO microflowers incorporated with graphene oxide and reduced graphene oxide hybrid materials [10730-11]

INNOVATIVE PATTERNING AND MATERIALS ENGINEERING FOR PHOTONICS APPLICATION

$10730 \mathrm{OF} \quad$ Comparing roll-to-roll and laser-assisted hot embossing for micro- and nanofabrication [10730-13]

$10730 \mathrm{OH}$ Increasing productivity of ultrashort pulsed laser ablation for commercialization of micro structuring [10730-15]

$10730 \mathrm{JJ}$ Towards mass fabrication of hot embossed plant surface texture replicas as photovoltaic cover layers [10730-17]

$10730 \mathrm{OL} \quad$ Electrical and optical properties of nickel-doped $\mathrm{Ge}_{2} \mathrm{Sb}_{2} \mathrm{Te}_{5}$ films produced by magnetron cosputtering [10730-19]

\section{DEVICES AND PROPERTIES OF NANOSTRUCTURES FOR PHOTONICS}

1073000 Waveguide grating as a Bragg mirror on Bloch surface waves based platform for 2D integrated optics applications [10730-22] 
10730 OR Size reduction of high-channel $\mathrm{Si}_{3} \mathrm{~N}_{4}$ based AWG-spectrometer for medical applications [10730-25]

10730 OU Plasmonic-ceria nanoparticles for automated optical fluorescence-quenching of dissolved oxygen [10730-28]

10730 OV Metaheuristic optimization of tapers for coupling to periodical subwavelength waveguides [10730-29]

LIGHT-MATTER INTERACTIONS IN ID AND 2D NANOMATERIALS

$1073014 \quad$ Laser pulse self-similar propagation in a medium with noble metal nanoparticles under conditions of non-stationary processes [10730-38]

\section{SCALABLE NANOMANUFACTURING OF 1D AND 2D NANOMATERIALS}

1073016 Fabrication of shape memory alloy based micro robot by using focused ion beam milling process and actuation using ultraviolet laser [10730-40]

\section{POSTER SESSION}

1073019 Optical up-conversion erbium-doped nanoparticles as coaters for solar cells efficiency improvement [10730-42]

$107301 \mathrm{~A} \quad$ Efficient coupling and transmission of cylindrical vector beams in a ring-core fiber [10730-43]

$10730 \mathrm{lF} \quad$ A design method of gap filling type micro lens array to improve homogeneity and maintain efficiency [10730-49]

$107301 G \quad$ Microstructure and low-temperature plastic deformation mechanisms of UFG copper [10730-50]

$107301 \mathrm{~K} \quad$ Radiation-induced synthesis and modification of soft nanomaterials for medical applications [10730-54]

$10730 \mathrm{lL} \quad$ Innovative approaches to combat healthcare-associated infections using efficacy standards developed through industry and federal collaboration [10730-55]

$107301 \mathrm{P} \quad$ Intermixed InGaAsP MQW tunable laser diode suitable for probing surface plasmon resonance optical sensor [10730-60]

$107301 \mathrm{R} \quad$ Optical characterization of polystyrene and ZnO [10730-62] 


\section{Authors}

Numbers in the index correspond to the last two digits of the seven-digit citation identifier (CID) article numbering system used in Proceedings of SPIE. The first five digits reflect the volume number. Base 36 numbering is employed for the last two digits and indicates the order of articles within the volume. Numbers start with 00, 01, 02, 03, 04, 05, 06, 07, 08, 09, OA, OB...0Z, followed by 10-12, 20-2Z, etc.

Agha, Imad, OL

Ahn, Sung-Hoon, 16

Al-Sheikhly, Mohamad, $1 \mathrm{~K}$

Azab, M., OU

Bornschlegel, Benedikt, $\mathrm{OH}$

Brenner, Andreas, $\mathrm{OH}$

Brenner, Philipp, OF

Buranasiri, Prathan, $0 \mathrm{C}$

Burrow, Joshua A., OL

Burtscher, C., OR

Casas Soler, Pere, OJ

Catterton, Devyn, 1K

Cowan, Troy E., $1 \mathrm{~L}$

D. Sisnando, A., OV

Drexler, W., OR

Dubey, R., 00

Edlinger, J., OR

Eschenbaum, Carsten, OF

Fang, Juncheng, 07

Finger, Johannes, $\mathrm{OH}$

França-Vieira, L., OV

Fritz, Benjamin, 0J

Geidarov, V., $1 G$

Gomard, Guillaume, 0J

Grigorova, T., 1G

Guggilla, Padmaja, 1R

Guo, Pengfei, OL

Guttmann, Markus, OF, OJ

$\mathrm{Ha}$, Dongheon, OA

Habermehl, Anne, OF

Hainberger, R., OR

Hajjiah, A., 19

Herzig, H. P., 00

Huber, Robert, OF

Huenig, Ruben, 0J

Kandas, I., OU

Kasianowicz, John J., $1 \mathrm{~K}$

Kassu, Aschalew, IR

Kekalo, Katerina, OB

Kim, Min-Soo, 16

Koppitsch, G., OR

Kraft, J., OR

Langenhorst, Malte, OJ

Lee, Eldred, OB

Lee, Hyun-Taek, 16

Lee, Kang-In, 16

Lei, Ting, 07, $1 \mathrm{~A}$

Lemmer, Ulrich, OF, OJ

LiKamWa, Patrick, IP

Liu, Jifeng, OB

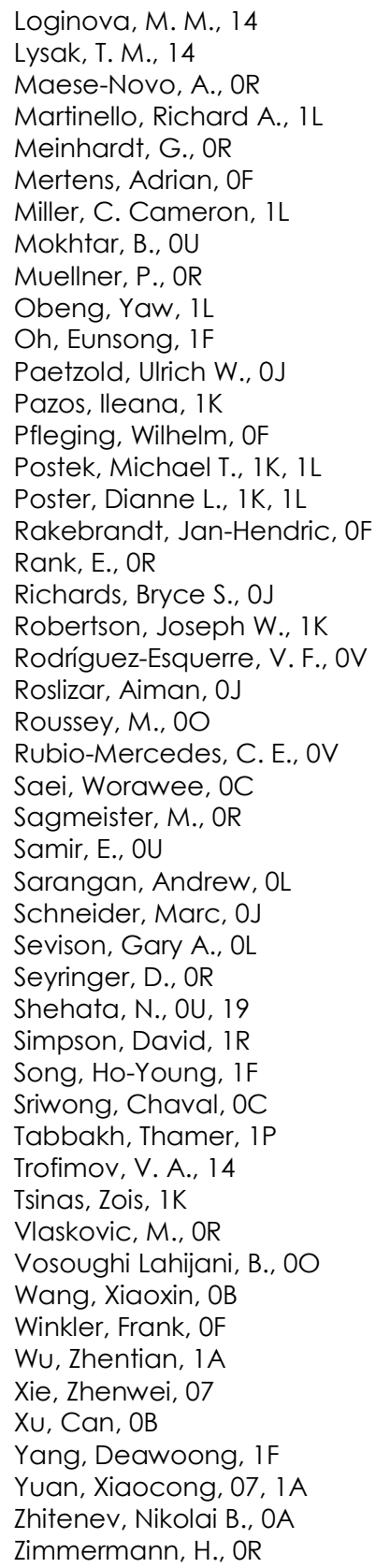


Proc. of SPIE Vol. $107301073001-6$

Downloaded From: https://www.spiedigitallibrary.org/conference-proceedings-of-spie on 26 Apr 2023 Terms of Use: https://www.spiedigitallibrary.org/terms-of-use 


\section{Conference Committee}

Symposium Chairs

Halina Rubinsztein-Dunlop, The University of Queensland (Australia)

Mark L. Brongersma, Geballe Laboratory for Advanced Materials

(GLAM), Stanford University (United States)

Symposium Co-chairs

Harry A. Atwater Jr., California Institute of Technology (United States)

Nikolay I. Zheludev, Optoelectronics Research Centre

(United Kingdom) and Nanyang Technological University

(Singapore)

Conference Chairs

Balaji Panchapakesan, Worcester Polytechnic Institute (United States)

Anne E. Sakdinawat, SLAC National Accelerator Laboratory (United States)

André-Jean Attias, Université Pierre et Marie Curie (France)

Elizabeth A. Dobisz, Spin Transfer Technologies, Inc. (United States)

Conference Program Committee

Maziar Ghazinejad, California State University, Fresno (United States)

Sarah Haigh, The University of Manchester (United Kingdom)

Ghassan E. Jabbour, Arizona State University (United States)

Robert Magnusson, The University of Texas at Arlington (United States)

Won Park, University of Colorado at Boulder (United States)

Dorota A. Pawlak, Institute of Electronic Materials Technology (Poland)

Michael T. Postek, (Retired) National Institute of Standards and Technology (United States)

Dianne L. Poster, National Institute of Standards and Technology (United States)

Jun Tanida, Osaka University (Japan)

Richard Tiberio, Stanford University (United States)

Chee Wei Wong, Columbia University (United States)

Wei Wu, The University of Southern California (United States) 


\section{Session Chairs}

$1 \quad$ Nano and Micro Optics

Balaji Panchapakesan, Worcester Polytechnic Institute (United States)

2 Energy Harvesting and Storage Technology

André-Jean Attias, Université Pierre et Marie Curie (France)

3 Innovative Patterning and Materials Engineering for Photonics Application

Anne E. Sakdinawat, SLAC National Accelerator Laboratory (United States)

Balaji Panchapakesan, Worcester Polytechnic Institute (United States)

4 Devices and Properties of Nanostructures for Photonics

Anne E. Sakdinawat, SLAC National Accelerator Laboratory (United States)

André-Jean Attias, Université Pierre et Marie Curie (France)

5 Light-Matter Interactions in 1D and 2D Nanomaterials

André-Jean Attias, Université Pierre et Marie Curie (France)

Balaji Panchapakesan, Worcester Polytechnic Institute (United States)

6 Scalable Nanomanufacturing of 1D and 2D Nanomaterials

André-Jean Attias, Université Pierre et Marie Curie (France) 